\title{
PHARMACOLOGICAL STUDIES ON EXPERIMENTAL NEPHRITIC RATS (2). ANTINEPHRITIC EFFECT OF VARIOUS DRUGS ON MASUGI'S NEPHRITIS
}

\author{
Yoshio SUZLKI, Mikio ITO and Tadashi NAGAMATSU \\ Department of Pharmacology. Faculty of Pharmacy, Meijo University. \\ Tenpakti-ku, Nagoya 468, Japan
}

Accepted October 19, 1977

\begin{abstract}
Masugi's nephritis was induced in rats by a single i.v. injection of antikidney serum from rabbits immunized with the homogenate of rat whole kidneys. The antinephritic effect of drugs was evaluated through determination of biochemical parameters such as contents of protein and cnzymes excreted into the urine and serum cholesterol content by the preadministration and intermittent administration tests. In the preadministration test, of test drugs, betamcthasone $(0.2 \mathrm{mg} / \mathrm{kg}-3$ p.o. $)$ and azathioprine $(25 \mathrm{mg} / \mathrm{kg}: 3$ p.o.) showed an antinephritic effect. Betamethasone in particular resuled in normalization of urine and serum parameters. In the intermiitent test, all drugs tested were effective. Significant recovery effects were observed with betamethasone ( $0.1 \mathrm{mg} / \mathrm{kg} \pm 6 \mathrm{p} .6$.$) , prednisolone (5 \mathrm{mg} / \mathrm{kg} .1 .6 \mathrm{p} .0$.$) , azathioprine$

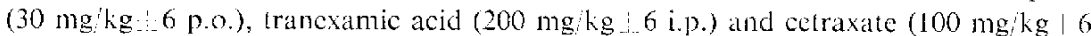
i.p.) on urinary protein excretion and with all test drugs including indomethacin (5 mg: $\mathrm{kg} .6 \mathrm{p} . \mathrm{o}$.) and cyclophosphamide $(2.5 \mathrm{mg} / \mathrm{kg} \perp 6$ p.o.) on urinary enzyme excretions. Serum cholesterol levels reverted to normal levels after administration of betamethasone. Using this nephritie model, the antinephritic effect of drugs could be tentatively evaluated.
\end{abstract}

As one of experimental models of nephritis, renal injury produced by chemical materials such as mercuric chloride, uranium, potassium chromate, cantaridine and arsenic acid has hitherto been employed. Although these models produce resulis similar to cases of acute renal insufficiency, results are different in the case of glomerulonephritis. Since Masugi (1) succeded in producing an experimental nephritic model by the injection of anti-kidney serum into rats or rabbits in 1934, pathologists and clinicians have concentrated on the studies of nephritic models based on immune mechanisms (2-5). We previously reported that in addition to protein, enzymes such as alkaline phosphatase and lactic dehydrogenase were markedly excreted into urine in Masugi's type of nephritis in rats $(6,7)$. The present study was designed to estimate the antinephritic effect of various drugs by employing the same Masugi model.

\section{MATERIALS AND METHODS}

\section{Experimental nephitis}

Experimental nephritis was produced in male Wistar rats weighing about $120 \mathrm{~g}$ by the i.v. injection of $0.7 \mathrm{ml} / 100 \mathrm{~g}$ of body weight of anti-rat kidney rabbit serum (anti-kidney serum) by the method described in a previous paper (6). 
Evaluation of antinephritic effect of drugs

The antinephritic effect of drugs was tested in two ways. In the first experiment, each test drug was given to a group of 8 rats once a day for 3 consecutive days from the 2 nd day before the injection of anti-kidney scrum. Each drug was dissolved in $0.9 \%$ saline or suspended in saline solution of $1 \% \mathrm{gum}$ arabic and given p.o. or i.p. in a volume of $1 \mathrm{ml} / 100 \mathrm{~g}$ of body weight. In addition to the above drug-treated nephritic (test drug) group, the nephritic (control) and non-nephritic (normal) groups were set in the experiment. The control group was given i.v. $0.7 \mathrm{ml} / 100 \mathrm{~g}$ of body weight of anti-kidney serum and $0.9 \%$ saline of the same volume instead of test drug. The normal group was given i.v. $0.7 \mathrm{ml} /$ $100 \mathrm{~g}$ of the serum only from normal rabbits instead of anti-kidney serum. The $24 \mathrm{hr}$ urine samples from the 9 th to the 10 th days after the anti-kidney scrum injection were collected and on the 10 th day, blood samples were obtained. Though determination of biochemical parameters in the urine and serum (urine: protein content and alkaline phosphatase and lactic dehydrogenase activities; serum: cholesterol content) according to the methods (6) as previously described, the effect of each test drug was evaluated. This is referred to as a preadministration test.

In the second experiment, each test drug was given to a group of 8 rats once daily $\times 3$ before the anti-kidncy serum injection. For the following 3 days, each test drug was withheld and then given again once daily $\times 3$ on the $4 \mathrm{lh}, 5$ th and 6 th days in the same doses as before. On the 10 th day, the rats were sacrificed and several biochemical parameters in the urine and serum were determined as in the preadministration test. This is reforred to as the intermittent administration test.

The efficacy of each test drug was expressed as a percent recovery as shown in Tables.

Student's t-test was used for statistical evaluations.

\section{Drugs}

The following drugs were applied. Stcroidal anti-inflammatory agents: Prednisolone (Toyo Jozo Co., Ltd.) and betamethasone (Toyo Jozo Co., Ltd.). Immunosuppressive agents: Azathioprine (Tanabe Seiyaku Co., Ltd.) and cyclophosphamide (cndoxan, Shionogi Seiyaku Co, Ltd.). Antiplasmins: Tranexamic acid (Daiichi Seiyaku Co, Ltd.) and cetraxate (DV-1006, Daiichi Seiyaku Co., Ltd.) (8). A non-steroidal anti-inflammatory agent: Indomethacin (Merck-Banyu Co., Ltd.).

\section{RESULTS}

\section{Antinephritic effects of drugs in preadministration test}

Effects on the urinary excretion of protein: As shown in Table 1, the urinary excretion of protein ( $\mathrm{mg} / 24 \mathrm{hr}$ urine) in the control group brought about a sharp increase of $1917.6 \%$ in comparison with the normal group. Betamcthasone $(0.2 \mathrm{mg} / \mathrm{kg} \times 3$ p.o.), a steroidal anti-inflammatory agent, resulted in a significant recovery effect of about $30 \%$ on the urinary excretion of protein. However, prednisolone $(10 \mathrm{mg} / \mathrm{kg} \times 3$ p.o. $)$, another steroid, was ineffective. Of two immunosuppressive agents, only azathioprine (25 $\mathrm{mg} / \mathrm{kg} \times 3$ p.o.) exhibited a recovery effect of about $70 \%$, being the most potent of the drugs tested. With 
TABLE 1. Ellects of various drugs in the preadministration test on the urinary excretion of protein in experimental ncphritic rats

\begin{tabular}{|c|c|c|c|c|}
\hline Groups & \multicolumn{2}{|c|}{$\begin{array}{c}\text { Dose } \\
\mathrm{mg} / \mathrm{kg} \times 3\end{array}$} & mg/24 hr urine & \multirow[t]{2}{*}{$\%$ recovery } \\
\hline Normal group & & & $11.4 \pm 2.6$ & \\
\hline Control group & & & $230.0=40.7$ & $(1917.6)$ \\
\hline \multicolumn{5}{|l|}{ Test drug groups } \\
\hline Prednisolone & 10 & p.o. & $194.3+34.4$ & 16.3 \\
\hline Betamethasonc & 0.2 & p.o. & $158.2 \pm 20.1^{*}$ & 32.8 \\
\hline Azathioprine & 25 & p.o. & $82.5+12.3^{* * *}$ & 67.5 \\
\hline Cyclophosphamide & 10 & p.o. & $207.4 \div 36.8$ & 10.3 \\
\hline Trancxamic acid & 200 & i.p. & $264.0-42.6$ & -15.5 \\
\hline Cetraxute & 100 & i.p. & 180.2137 .8 & 22.8 \\
\hline Indomethacin & 5 & p.o. & $174.4-30.8$ & 25.4 \\
\hline \multicolumn{5}{|c|}{$\begin{array}{l}\text { Results are mean }-\mathrm{S} . \mathrm{E} \text {, obtained from } 8 \text { rats. \% recovery }-\mathrm{C}-\mathrm{T}-\mathrm{C} \times 100(\mathrm{C} \text { : } \\
\text { control, } \mathrm{T} \text { : test drug, } \mathrm{N} \text { : normal). The number in parenthesis indicates } \\
\text { percent increase of control to normal. Asterisk indicates a significant difference } \\
\text { from control }(* * *: P-0.001, *: \mathrm{P} 0.05) .\end{array}$} \\
\hline
\end{tabular}

tranexamic acid and cetraxate, antiplasmin agents and indomethacin, a non-steroidal antiinflammatory agent, there was no significant recovery.

Effects on the atinary excretions of alkaline phosphatase and lactic dehydrogenase: As indicated in Table 2, the urinary excretion of alkaline phosphatase (Bessey-Lowry unit/24 hr urine $\left.\times 10^{2}\right)$ in control group induced a marked increase of $1060.0 \%$ in comparison with normal group. Both betamethasone $(0.2 \mathrm{mg} / \mathrm{kg} \times 3$ p.o.) and azathioprine $(25 \mathrm{mg} / \mathrm{kg} \times 3$ p.o.) which were effective against the proteinuria also exhibited a significant recovery effect on the urinary excretion of this enzyme. Indomethacin $(5 \mathrm{mg} / \mathrm{kg} \times 3$ p.o.) also exerted a significant recovery effect.

TAlbe: 2. Effects of various drugs in the preadministration test on the urinary excretions of alkaline phosphatase and lactic dehydrogenase in experimental nephritic rats

\begin{tabular}{|c|c|c|c|c|c|c|}
\hline \multirow[t]{2}{*}{ Groups } & \multirow{2}{*}{\multicolumn{2}{|c|}{$\begin{array}{c}\text { Dose } \\
\mathrm{mg} / \mathrm{kg} \times 3\end{array}$}} & \multicolumn{2}{|c|}{ Alkaline phosphatase } & \multicolumn{2}{|c|}{ Lactic dehydrogenase } \\
\hline & & & $\begin{array}{l}\text { Besscy-Lowry unit } \\
24 \text { hr urine } \times 10^{2}\end{array}$ & $\begin{array}{l}\% \\
\text { rocovery }\end{array}$ & $\begin{array}{l}\text { Hill unit/24 hr } \\
\text { urine } \times 10^{2}\end{array}$ & $\begin{array}{c}\% \\
\text { recovery }\end{array}$ \\
\hline Normal group & & & $0.5 \cdot 0.1$ & & $14.1 \quad 1.7$ & \\
\hline Control group & & & $5.8 \div 1.1$ & $(1060.0)$ & $99.9+15.9$ & $(608.6)$ \\
\hline \multicolumn{7}{|l|}{ Test drug groups } \\
\hline Prednisolone & 10 & p.o. & $4.1 \ldots 0.8$ & 32.1 & $66.7 \div 10.1$ & 38.7 \\
\hline Betamethasone & 0.2 & p.o. & $3 . I \ldots 0.4^{*}$ & 50.9 & $31.9=5.3^{* *}$ & 79.3 \\
\hline Azathioprine & 25 & p.o. & $2.8=0.3^{* * *}$ & 56.6 & $85.1 \div 15.3$ & 17.2 \\
\hline Cyclophosphamide & 10 & p.o. & $3.7 \perp 0.7$ & 39.6 & $62.4 \pm 12.4$ & 43.7 \\
\hline Tranexamic acid & 200 & i.p. & $5.8 \pm 1.4$ & 0 & 72.213 .8 & 32.3 \\
\hline Celraxate & 100 & i.p. & $3.8: 0.6$ & 37.7 & $99.9 \div 18.1$ & 0 \\
\hline Indomethacin & 5 & p.o. & $3.2-0.2^{*}$ & 49.1 & $43.0 \therefore 8.0^{k}$ & 66.3 \\
\hline
\end{tabular}

Asierisk indicates a significant difference from control $(* *: P<0.01, * ; P<0.05)$. Other cxplanations as in Table 1. 
The increase of urinary excretion of lactic dehydrogenase (Hill unit/24 hr urine $\times 10^{2}$ ) induced by nephritis was less than that of alkaline phosphatase, being $608.6 \%$ higher than normal level. Betamethasone $(0.2 \mathrm{mg} / \mathrm{kg} \times 3$ p.o.) and indomethacin $(5 \mathrm{mg} / \mathrm{kg} \times 3$ p.o.) induced a recovery effect of over $60 \%$ on the excretion of this enzyme.

Effects on serum cholesterol content: As shown in Table 3, the cholesterol content in serum ( $\mathrm{mg} / \mathrm{d} 1$ ) of the control group was $115.5 \%$ higher than that of normal group. None of test drugs showed a significant recovery effect. With betamethasone and azathioprine, there was only a slight tendency toward recovery.

\section{Antinephritic effects of arugs in intermittent administration test}

Effects on the urinary excretion of protein: As given in Table 4, the urinary excretion of protein ( $\mathrm{mg} / 24 \mathrm{hr}$ urine) in the control group induced a marked increase of $1599.1 \%$ as compared with normal group. Prednisolone $(5 \mathrm{mg} / \mathrm{kg} \times 6$ p.o.) and betamethasone $(0.1$

TABLI: 3. Effects of various drugs in the preadministration test on serum cholesterol level in experimental nephritic rats

\begin{tabular}{|c|c|c|c|}
\hline Groups & $\underset{\mathrm{mg} / \mathrm{kg} \times 3}{\operatorname{Dose}}$ & $\mathrm{mg} / \mathrm{dl}$ & $\%$ recovery \\
\hline Normal group & & $68.4+4.2$ & \\
\hline Control group & & $147.4 \pm 21.5$ & $(115.5)$ \\
\hline \multicolumn{4}{|l|}{ Test drug groups } \\
\hline Prednisolone & 10 p.o. & $144.9 \perp 15.1$ & 3.2 \\
\hline Betamethasone & 0.2 p.o. & $103.9 \pm 16.8$ & 55.1 \\
\hline A7athioprine & 25 p.o. & $104.3 \perp 20.2$ & 54.6 \\
\hline Cyclophosphamide & p.o. & $136.9 \pm 18.2$ & 13.3 \\
\hline Tranexamic acid & 200 & $145.3 \div 21.0$ & 2.7 \\
\hline Cetraxate & 100 & $134.9 ! 11.8$ & 15.8 \\
\hline Indomethacin & p.o. & $181.0+14.3$ & -42.5 \\
\hline
\end{tabular}

Explanations as in Table 1.

TABLE 4. Effects of various drugs in the intemittent administration test on the urinary excretion of protein in experimental nephritic rats

\begin{tabular}{|c|c|c|c|}
\hline Groups & $\begin{array}{c}\text { Dose } \\
m g / k g \times 6\end{array}$ & $\mathrm{mg} / 24 \mathrm{hr}$ urine & $\%$ recovery \\
\hline Normal group & & $11.1 \div 1.4$ & \\
\hline Control group & & $188.6-30.1$ & $(1599.1)$ \\
\hline \multicolumn{4}{|l|}{ Test drug groups } \\
\hline Prednisolone & 5 p.o. & $68.3+13.6^{* * *}$ & 67.8 \\
\hline Betamethasone & 0.1 p.o. & $63.7+15.3^{* * * 1}$ & 70.4 \\
\hline Azathioprine & 30 p.o. & $102.3 \perp 14.9^{*}$ & 48.6 \\
\hline Cyclophosphamide & 2.5 p.o. & $159.6 \pm 20.8$ & 16.3 \\
\hline Tranexamic acid & 200 i.p. & $75.8 \pm 11.6^{*}$ & 63.5 \\
\hline Cetraxate & 100 & $110.1 \pm 16.7^{*}$ & 44.2 \\
\hline Indomethacin & p.o. & $185.3+34.3$ & 1.6 \\
\hline
\end{tabular}

Asterisk indieates a significant difference from control $\left(^{* * *}: \mathrm{P}<0.001\right.$, ${ }^{*}: k$ : $\mathrm{P} 00.01, *: \mathrm{P}(0,05)$. Other explanations as in Table 1. 
$\mathrm{mg} / \mathrm{kg} \% 6$ p.o.) resulted in a potent recovery eflect of about $70 \%$ on the urinary excretion of protein. Tranexamic acid $(200 \mathrm{mg} / \mathrm{kg} \times 6 \mathrm{i} . \mathrm{p}$.) was effective next to both steroids. Azathioprine $(30 \mathrm{mg} / \mathrm{kg} \times 6$ p.o.) and cetraxate $(100 \mathrm{mg} / \mathrm{kg} \times 6 \mathrm{i} . \mathrm{p}$.) had significant recovery effects of over $40 \%$

Effects on urinary excretions of alkaline phosphatase and lactic dehydrogenase: $\Lambda \mathrm{s}$ seen in Table 5, the urinary exeretion of alkaline phosphatase (Bessey-Lowry unit/24 hr urine $\times 10^{2}$ ) in control group calused a strong increase of $500.0 \%$ in comparison with normal group. With all test drugs, except for prednisolone, significant recovery effects were recognized on the excretion of this enzyme. Betamethasone $(0.1 \mathrm{mg} / \mathrm{kg} \times 6$ p.o.), trancxamic acid (200 $\mathrm{mg} / \mathrm{kg} \times 6 \mathrm{i} . \mathrm{p}$.) and cetraxate $(100 \mathrm{mg} / \mathrm{kg} \% 6 \mathrm{i.p.})$ in particular resulted in normalization of this parameter.

TABLE 5. Ellects of various drugs in the intermiltent administration test on the urinary exeretions of alkaline phosphatase and lactic dehydrogenase in experimental nephritic rats

\begin{tabular}{|c|c|c|c|c|c|}
\hline \multirow[t]{2}{*}{ Groups } & \multirow{2}{*}{$\begin{array}{c}\text { Dose } \\
\text { mg } k g \times 6\end{array}$} & \multicolumn{2}{|c|}{ Alkaline phosphatase } & \multicolumn{2}{|c|}{ Lactic dehydrogenase } \\
\hline & & $\begin{array}{l}\text { Bessey-Lowry unit } \\
24 \text { lir urine } 10^{\prime}\end{array}$ & $\begin{array}{c}0 / 0 \\
\text { recovery }\end{array}$ & $\begin{array}{l}\text { Hill unit } 24 \mathrm{hr} \\
\text { urine } 10^{2}\end{array}$ & $\begin{array}{c}\% \\
\text { recovery }\end{array}$ \\
\hline Normal group & & $0.6+0.4$ & & $11.4 .: 6.8$ & \\
\hline Control group & & $3.6 \quad 0.8$ & $(500.0)$ & $32.2 ! 11.8$ & $(182.5)$ \\
\hline Test drug groups & & & & & \\
\hline Prednisolone & p.o. & $3.2 \ldots 0.6$ & 13.3 & $15.5 \div 3.0^{*}$ & 80.3 \\
\hline Betamethasone & 0.1 p.o. & $0.7 \ldots 0.7^{* \cdots * *}$ & 96.7 & $11.2: 4.4^{* * *}$ & 101.0 \\
\hline Azathioprine & 30 p.o. & $1.8 \div 0.2^{*}$ & 60.0 & $22.0 ! 7.2$ & 49.0 \\
\hline Cychophosphamide & 2.5 p.o. & $2.10 .6^{*}$ & 50.0 & $20.1 \div 9.4$ & 58.2 \\
\hline Tranexamic acid & 200 i.p. & $0.5=0.3^{* * *}$ & 103.3 & $25,0-7.8$ & 34.6 \\
\hline Cetraxato & i.p. & $0.7: 0.8 * \cdots$ & 96.7 & 22.3 .11 .3 & 47.6 \\
\hline Indomethacin & p.o. & $1.2=0.5^{* * k}$ & 80,0 & $25.4 \div-9.0$ & 32.7 \\
\hline
\end{tabular}

Asterisk indicates a significant difference from control $(* * *: P 0.001, * *: P<0.01$,

$*: P(0.05)$. Other explanations as in Table 1 .

TAlsı. 6. Elfects of various druess in the intermittent administration lest on serum cholesterol level in experimental nephritic rats

\begin{tabular}{|c|c|c|c|}
\hline Groups & $\begin{array}{c}\text { Dose } \\
\text { mgikg } 6\end{array}$ & mgidl & o recovery \\
\hline Normal group & & $70.8 . !-3.2$ & \\
\hline Control group & & $155.2 \div 25.9$ & $(119.2)$ \\
\hline \multicolumn{4}{|l|}{ Test drug groups } \\
\hline Prednisolone & 5 p.o. & $133.2 \ldots 14.2$ & 26.1 \\
\hline Betamethasone & $0.1 \mathrm{p} .0$. & $67.8 \cdots 10.8^{2 * * *}$ & 103.6 \\
\hline Azathioprine & 30 p.o. & $110.3 \ldots 19.7$ & 53.2 \\
\hline Cyclophosphamide & 2.5 p.o. & $153.7-23.0$ & 1.8 \\
\hline Trancxamic acid & 200 i.p. & $112.2: 13.3$ & 50.9 \\
\hline Celraxate & 100 & $95.3 \cdots 20.1$ & 71.0 \\
\hline Indomethacin & p.o. & $123.1: 13.8$ & 38.0 \\
\hline
\end{tabular}

Asteristi indicates a significant difference from control at P. 0.01 . Other explanalions as in Table 1. 
On the other hand, the urinary excretion of lactic debydrogenase (Hill unit/24 hr urine $\left.\times 10^{2}\right)$ due to nephritis was only the increase of $182.5 \%$ against normal level. Both steroids, prednisolone $(5 \mathrm{mg} / \mathrm{kg} \times 6$ p.o.) and betamethasone $(0.1 \mathrm{mg} / \mathrm{kg} \times 6$ p.o.) showed recovery effects more than $80 \%$ on this enzyme excretion. Cyclophosphamide ( $2.5 \mathrm{mg} / \mathrm{kg} \times 6$ p.o.), azathioprine $(30 \mathrm{mg} / \mathrm{kg} \times 6$ p.o.) and cetraxate $(100 \mathrm{mg} / \mathrm{kg} \times 6$ i.p.) exhibited only a tendency of recovery effects.

Effects on serum cholesterol content: As illustrated in Table 6, the cholesterol content in serum (mg/dl) of control group was $119.2 \%$ more than that of normal group. Scrum cholesterol levels returned to normal levels with betamethasone $(0.1 \mathrm{mg} / \mathrm{kg} \times 6$ p.o. $)$. or other test drugs, azathioprine $(30 \mathrm{mg} / \mathrm{kg} \times 6$ p.o.), tranexamic acid (200 $\mathrm{mg} / \mathrm{kg} \times 6$ i.p.) and cetraxate $(100 \mathrm{mg} / \mathrm{kg} \times 6 \mathrm{i} . \mathrm{p}$.) exhibited only the tendency of recovery effects.

\section{DISCUSSION}

Effects of drugs on parameters which clearly indicate the development of nephritis are required for correct evaluations of antinephritic effects. Of several biochemical parameters determined in the present experiments, the urinary excretions of protein and enzymes such as alkaline phosphatase and lactic dehydrogenase appear to be the most suitable for this purpose. Among the test drugs, betamethasone, a steroid, and azathioprine, an immunosuppressant, showed a potent antinephritic effect by inhibiting the changes in these parameters due to nephritis, in the preadministration test. This effect of both drugs may be partially due to the inhibition of the injury of renal tissue subsequent to antigen-antibody reaction after administration of anti-kidney serum.

On the other hand, following the intermittent administration, all drugs tested were effective against nephritis. Azathioprine was considerably effective in both tests, while cyclophosphamide had a moderatc effect, in the intermittent administration test. Miyakawa et al. (9) investigated the effects of prednine and cyclophosphamide on the chemical composition of glomerular basement membrane by using the model of nephrotoxic nephritis in rats and reported that an immunosuppressant exhibited more therapeutic effects than did a steroid. Tranexamic acid and cetraxate, antiplasmin agents, showed a significant antinephritic action only through the intermittent administration test. Edward et al. (10) showed that plasmin activity in plasma and urine was elevated in various renal diseases. Kobayashi et al. (11) reported that antiplasmins were effective in treating chronic nephritic diseases. At present there are few drugs which have a marked efficiency in cases of nephritis and an antiplasmin agent may be worthy of application in the clinical field. Although indomethacin, a non-steroidal anti-inflammatory agent, inhibited enzyme excretions into urine, there were no effects on proteinuria. However, Vihert et atl. (12) reported that this drug was considerably effective in reducing proteinuria and in improving the course of diffuse glomerulonephritis under experimental and clinical conditions. The discrepancy in the results is mainly attributed to the difference in experimental models.

In the present experiments, the effect of drugs on Masugi's nephritis in rats was tentatively evaluated through determination of several biochemical parameters in urine and 
serum. On the other hand, Shibata et al. $(4,5)$ reported that a chronic nephritis which developed slowly could be induced in rats with a single i.v. administration of anti-serum obtained with the purified antigen of kidney. Possible effects of drugs on this chronic model are under investigation in our laboratory.

\section{REFERENCES}

1) Masugi, M.: Über die experimentelle Glomerulonephrilis durch das spezifische Antinierenserum. Ein Beitrag zur Pathogenese der diffusen Glomerulonephricis. Beitr. path. Anat. 92, 429-466 (1934)

2) KAY, C.F.: The mechanism by which experimental nephritis is produced in rabbits injected with nephrotoxic duck scrum. J. exp. Wed. 72, 559-571 (1940)

3) Fummoto, T., Okada, M., Kondo, Y. ANd TAda, T.: The nature of Masugi nephritis. Histoand immunopathological studies. Acta Path. Japan. 14, 275310 (1964)

4) Sullibata, S., Nagasawa, T., Takuma, T., Narusl, T. and Mirakawa, Y.: Isolalion and properties of the soluble antigen specific for the production of nephrotoxic glomerulonephritis. I. Immunopahological demonstration of the complete antigenicity of the soluble antigen. Japan. J. exp. Med. 36, 127-142 (1966)

5) Shubata, S., Nagasawa, T., Narlse, T. àd Mryakawa, Y.: Glomerulonephritis induced in rats by antiserum against a glycoprotein from rat kidney. - New experimental model of glomerulonephritis-. Japan. J. exp. Med. 37, 337-353 (1967)

6) SLZZUKI, Y., INA, K., HARADA, M. AND YAMAGA MI, J. : Pharmacological studies on experimental nephrotic rats (1). Experimental production of anti-scrum nephrosis in rats and changes of renal enzyme activitics. Folia pharmacol. japon. 68, 572-585 (1972) (in Japanese)

7) Suzlki, Y., INA, K. ANd Yamagami, I.: Plarmacological studics on diuretics (6). Activities of various diuretics on experimental nephrotic rats. Folia phamacol. japon. 69, 739-748 (1973) (in Japanese)

8) SUZUKI, Y., HAYASHI, M., ITO, M. AND YAMAGAMI, 1.: Anti-ulcer effects of 4'-(2-carboxyethyl) phenyl trans-4-aminonethyl cyclohexanecarboxylate hydrochloride (celraxate) on various experimental gastric ulcers in rals. Japam. J. Pharmacol. 26, 471-480 (1976)

9) Miyakawa, T., Nozawa, Y., Kivoshita, Y., Isfmura, M. and Koidf, T.: Biochemical studies on the glomerular basement membrane (II). Eflects of immunosuppressants on the glomerular basement membrane of nephrotoxic nephritic rat. (1). Japan. $J$. Nephrology 16, 53-61 (1974) (in Japanese)

10) Edward, N., Young, D.P.-G. ANd Macleod, M.: Fibrinolytic activity in plasma and urine in chronic renal disease. J. clim. Path. 17, 365368 (1964)

11) Kobayashi, K., Shibata, M., Kato, K. and Yasuds, B.: Zinen no kōpurasuminryōhō. Antiplasmin Therapy, Edited by KaWakita, Y., Matsuoka, M. AND OKamoto, A., p. 247-266, Daiichi Seiyaku Co. Lid., Tokyo (1968) (in Japanese)

12) Vihert, A.M., Glezer, G.A., Mfgrelishvili, R.I. and RyfF, M.: The use of indomethacin for treatment diffuse glomerulonephritis under experimental and clinical conditions. Arzneim.-Forsch. 23, 991-996(1973) 